\title{
Determinan Kepemilikan Sumber Air Minum Rumah Tangga di Jawa Barat (Analisis Data Survei Demografi dan Kesehatan Indonesia (SDKI) Tahun 2012)
}

\author{
Pipit Herawati ${ }^{1}$, Kurnia Wahyudi ${ }^{2}$, Irvan Afriandi ${ }^{2}$ \\ ${ }^{1}$ Dinas Kesehatan Kabupaten Bandung Barat \\ ${ }^{2}$ Departemen Ilmu Kesehatan Masyarakat, Fakultas Kedokteran Universitas Padjadjaran
}

\begin{abstract}
Abstrak
Kekurangan air bersih merupakan salah satu faktor munculnya penyakit diare yang menjadi penyebab terbesar kedua terhadap kematian anak di bawah usia lima tahun. Terdapat banyak faktor yang memengaruhi kepemilikan sumber air bersih yang digunakan. Penelitian ini menggunakan data sekunder Survei Demografi dan Kesehatan Indonesia (SDKI) tahun 2012 di wilayah Provinsi Jawa Barat $(n=2.264)$ yang diperoleh secara umum melalui situs resmi DHS. Data yang digunakan merupakan data nominal dan ordinal, Beberapa variabel dikategorisasi ulang, kemudian seluruh variabel dianalisis menggunakan regresi logistik. Hasil yang didapatkan, variabel yang memiliki hubungan signifikan dengan kepemilikan SAM yang aman adalah jenis permukiman, jenis fasilitas sanitasi, pendidikan terakhir KK dan indeks kekayaan keluarga. Disamping itu, masih ditemukan disparitas antara rumah tangga yang tinggal di perkotaan dan pedesaan, di perkotaan masyarakat lebih mudah mengakses sumber air minum (SAM) yang aman sebesar 2 kali dibandingkan dengan masyarakat yang tinggal di pedesaan $[\mathrm{AOR}=1,97(\mathrm{IK} 95 \% 1,53 ; 2,53)]$. Hasil penelitian ini mendapatkan informasi bahwa Indeks kekayaan keluarga dan pendidikan memiliki hubungan yang positif dengan kepemilikan SAM. Semakin tinggi indeks kekayaan keluarga semakin dapat mengakses SAM yang aman.
\end{abstract}

Kata Kunci : Air Minum, Diare, Sanitasi, SDKI.

\section{Determinants of Household Drinking Water in West Java (An Analysis From Indonesia Demographic Health Survey (IDHS) 2012)}

\begin{abstract}
Lack of clean water may cause diarrhea that is the main cause mortality of children under five years old. Meanwhile, there are many factors that affect the ownership of clean water sources to be used. This study assesed Indonesia Demographic Health Survey (IDHS) 2012 data just only from West Java Province $(n=2.264)$. The data gained pulicly in DHS website freely. Furthermore, several variables were categorized, and then the whole variables were analyzed using logistic regression. Hereafter, according to the results obtained, variables that had significant relationship with the secure ownership of SAM were type of settlement, type of sanitation facilities, last education of KK and family wealth index. Moreover, there was still disparity found between households who lived in urban areas and those who lived in rural areas; in urban areas, people were more easier to access secure drinking water sources (SAM) twice as much those who lived in rural areas [AOR=1,97 (95\% CI: 1,53;2,53)]. Meanwhile, family wealth index and education had positive relationship with SAM ownership. The higher family wealth index the easier it was to access secure SAM / drinking water sources.
\end{abstract}

Keyword : Drinking water, Diarrhoea, Sanitation, IDHS.

Korespondensi:

Pipit Herawati, SKM

Dinas Kesehatan Kabupaten Bandung Barat, Komplek Pemkab Bandung Barat Gedung B Lantai 2

JI Raya Padalarang-Cisarua KM 2,5, Desa Mekarsari Kec. Ngamprah Provinsi Jawa Barat

Mobile : 081221466627

Email : pipitherawati03@gmail.com 


\section{Pendahuluan}

Air merupakan kebutuhan vital bagi kehidupan manusia. ${ }^{1}$ Kekurangan air bersih dapat menyebabkan terjadinya penyakit, salah satunya diare yang menjadi penyebab terbesar kedua kematian anak di bawah usia lima tahun. Sebanyak dua juta orang meninggal setiap tahun karena penyakit tersebut (sebagian besar adalah anakanak di negara berkembang). ${ }^{2}$ Dalam 10 tahun terakhir, diare telah menyebabkan kematian pada anak melebihi jumlah korban pada perang dunia ketiga yang telah berlangsung selama 60 tahun. Seorang anak meninggal setiap 15 detik karena diare yang disebabkan buruknya akses terhadap sanitasi dan air bersih. ${ }^{3}$ Begitupula di Indonesia, beberapa laporan dan penelitian menganalisis mengenai hubungan diare dengan buruknya sanitasi dan akses air minum yang tidak aman.

Komitmen global terhadap akses air minum yang aman dan sanitasi dasar yang diamanatkan melalui Millenium Developmen Goals (MDGs) 2015 yang kemudian dilanjutkan dalam Sustainable Development Goals (SDGs) 2030, hal tersebut menunjukan perhatian masyarakat global terhadap sanitasi dan air minum di seluruh dunia. ${ }^{4}$ Secara global, menurut data terakhir target SAM telah tercapai namun tidak pada sanitasi dasar. ${ }^{5}$ Selain itu, masih terjadi kesenjangan antara capaian di pedesaan dan perkotaan, sebesar $16 \%$ dan $4 \%$ untuk akses terhadap SAM layak dan $50 \%$ dan $18 \%$ untuk sanitasi dasar yang layak. ${ }^{5}$ Di lain pihak, target Sustainable Development Goals yang dioperasionalkan dalam RPJMN mengamanatkan Indonesia 100\% akses terhadap SAM dan sanitasi dasar layak pada tahun $2019 .{ }^{6}$ Sementara, saat ini cakupan sanitasi total mencapai $62 \%$, sehingga masih ada kesenjangan 38\% untuk mencapai target 100\%.

Secara global telah banyak penelitian mengenai hubungan akses terhadap SAM yang layak, namun penelitian yang menilai faktorfaktor yang berhubungan dengan akses terhadap SAM yang layak di Indonesia masih terbatas. Salah satu penelitian yang telah dilakukan dengan menggunakan data Indonesia Family Life Survey gelombang ke empat (IFLS-4) menemukan masih terdapat kesenjangan capaian akses antar beberapa pulau besar serta antara wilayah pedesaan dan perkotaan, begitupula status sosial-ekonomi menjadi penentu dalam pemilihan SAM. ${ }^{18}$ Hasil penelitian lain yang menganalisis data Survei Sosial Ekonomi Nasional (SUSENAS) menemukan perbedaan spasial akses air minum dan sanitasi yang layak di Indonesia, hasil penelitian tersebut juga menjelaskan bahwa taget pencapaian sanitasi masih jauh dari target dan perlu upaya yang lebih keras untuk dapat memenuhi jumlah yang ditargetkan. ${ }^{17}$ Pada Penelitian ini, penulis bertujuan untuk mengetahui faktor penentu terhadap pemilihan SAM yang aman di Provinsi Jawa Barat sebagai provinsi dengan jumlah penduduk terbanyak di Indonesia. ${ }^{7}$ dengan tingkat urbanisasi tertinggi ke tiga setelah DKI Jakarta dan DIY Yogyakarta. ${ }^{8}$ Tulisan ini bertujuan menginformasikan sumber air minum yang dipilih oleh masyarakat Jawa Barat beserta faktor-faktor yang memengaruhinya berdasarkan data IDHS tahun 2012. Hal ini menjadi salah satu upaya untuk menambah sumber informasi dalam pengembangan kebijakan dalam bidang sanitasi dan air minum di Jawa Barat untuk mencapai $100 \%$ akses sanitasi dasar dan air minum layak pada tahun $2019{ }^{6,9}$

\section{Metode}

Sumber data; Data penelitian ini diperoleh dari Survei Demografi dan Kesehatan Indonesia (SDKI) Tahun 2012. Survei tahun 2012 ini merupakan survei ke tujuh yang dilaksanakan di 33 Provinsi di Indonesia. Survei dilaksanakan oleh Badan Pusat Statistik (BPS) yang berkolaborasi dengan Badan Kependudukan dan Keluarga Berencana Nasional (BKKBN) dan Kementerian Kesehatan dan bekerja sama dengan ICF International sebagai pembantu teknis Demographic Health Survey program (MEASURE DHS) - United State Agency for International Development (USAID). Data set SDKI dapat diakses dengan persetujuan melalui alamat situs web resmi DHS-Program ( $w w w$. dhsprogram.com).

Populasi dan sampel; Survei Demografi dan Kesehatan Indonesia tahun 2012 dilaksanakan pada 33 Provinsi, mencakup 43.852 rumah tangga. Pada penelitian ini, hanya menggunakan data di Provinsi Jawa Barat dengan jumlah 2.264 rumah tangga.

Variabel terikat; Variabel terikat dari penelitian ini ialah SAM di tingkat rumah tangga. Berdasarkan Joint Monitoring Programme (JMP) dari World Health Organization (WHO) dan United Nations Children's Fund (UNICEF).3 Variabel terikat didefinisikan menjadi; Apabila rumah tangga menggunakan sumber air minum yang tidak aman (sumur gali tidak terlindungi di tingkat rumah tangga atau umum, mata air tidak terlindungi, sungai, danau, bendungan, air hujan, air yang berasal dari truk dan lainnya); Apabila rumah tangga menggunakan sumber air minum yang aman (perpipaan tingkat rumah tangga maupun umum, sumur gali yang terlindungi, mata air yang terlindungi serta air kemasan atau air isi ulang) 
Variabel bebas; Penelitian ini terdiri dari tujuh variabel bebas, antara lain: Jenis permukiman yang terdiri dari perkotaan (urban) dan pedesaan (rural). Kemudian fasilitas sanitasi yang dibagi menjadi; Tidak memenuhi syarat: jika fasilitas sanitasi atau toilet yang dimiliki milik pribadi namun tidak dilengkapi tangki septik, merupakan fasilitas milik umum atau berbagi dengan keluarga lain, buang air besar di tempat terbuka seperti di sungai/kebun/hutan; Memenuhi syarat: jika fasilitas sanitasi atau toilet yang digunakan milik pribadi dan dilengkapi dengan tangki septik. Variabel bebas ketiga yaitu jumlah penghuni rumah tangga berupa data numerik. Kelima, Status pernikahan dari kepala keluarga (KK) yang terbagi menjadi; Tidak/ belum menikah; Menikah dan; cerai. Variabel bebas ke empat yaitu jenis kelamin KK, variabel ke lima adalah pendidikan terakhir KK yang dibagi menjadi 5 kategori yaitu; Tidak sekolah; Tamat SD; Tamat SMP; Tamat SMA dan; Tamat Perguruan Tinggi. Variabel terakhir yaitu indeks kekayaan keluarga yang dibagi menjadi; Sangat miskin; Miskin: Menengah; Kaya dan; Sangat kaya.

Analisis statistik; Analisis statistik terdiri dari dua tahap. Pertama, analisis deskriptif untuk mengetahuidistribusifrekuensidarisetiapvariabel. Kedua, analisis multivariabel menggunakan analisis regresi logistik. Regresi logistik digunakan jika variabel respon bersifat kategorik (nominal atau ordinal) dengan variabel-variabel prediktor bersifat kontinu maupun kategorik.

Pemilihan variabel menggunakan metode backward dengan menggunakan software spss v.20, analisis dimulai dengan menguji seluruh variabel kemudian secara bertahap variabel yang memiliki nilai $\mathrm{p}<0,25$ dikeluarkan dari analisis. Proses akan berhenti sampai tidak ada lagi variabel yang dapat dikeluarkan dari analisis. Salah satu ukuran yang digunakan untuk menginterpretasi koefisien variabel prediktor adalah Odds rastio (OR) dan signifikansi nilai dilihat dari angka $p$ value $<0,05$.

$$
\log (y)-\frac{\exp (\beta 0+\beta 1 x 1+\cdots+\beta i x i)}{1+\exp (\beta 0+\beta 1 x 1+\cdots+\beta i x i)}
$$

Bentuk khusus dari model regresi logistik adalah sebagai berikut 10

$\mathrm{X} 1=$ variabel bebas ke 1

$\beta 1=$ koefisien dari variabel bebas ke 1

$\mathrm{Xi}=$ variabel bebas ke-i

$\beta \mathrm{i}=$ koefisien dari variabel bebas ke-i

\section{Hasil}

Sebagian besar rumah tangga sudah menggunakan sumber air minum yang aman $(81,5 \%)$. Sebanyak
$60,2 \%$ rumah tangga berada di wilayah perkotaan, dan sebagian lainnya termasuk dalam wilayah pedesaan $(39,8 \%)$. Dalam hal fasilitas sanitasi, hampir dua dari tiga rumah tangga $(63,4 \%)$ telah menggunakan fasilitas sanitasi yang memenuhi syarat. Mayoritas kepala keluarga telah menikah $(85,6 \%)$. Sebagian besar kepala keluarga berjenis kelamin laki-laki (85,5\%). Hampir setengah KK $(49,4 \%)$ berpendidikan SD. Sebesar $24,3 \%$ rumah tangga merupakan keluarga kaya sedangkan keluarga miskin dan sangat miskin sebanyak $17,4 \%$ dan $14 \%$. Rerata jumlah penghuni satu rumah tangga sebanyak 4 orang.

Tabel 1 Analisis Deskriptif Variabel ( $N=\mathbf{2 . 2 6 4}$ )

\begin{tabular}{|c|c|}
\hline Variabel (n) & Persen $(\%)$ \\
\hline \multicolumn{2}{|l|}{ Sumber air minum $(n=2.262)$} \\
\hline Tidak Aman & 18,5 \\
\hline Aman & 81,5 \\
\hline \multicolumn{2}{|l|}{ Permukiman $(\mathrm{n}=\mathbf{2 . 2 6 4})$} \\
\hline Perkotaan & 60,2 \\
\hline Pedesaan & 39,8 \\
\hline \multicolumn{2}{|l|}{ Fasilitas Sanitasi $(\mathrm{n}=\mathbf{2 . 2 6 3})$} \\
\hline Fasilitas tidak memenuhi syarat & 36,5 \\
\hline Fasilitas memenuhi syarat & 63,5 \\
\hline \multicolumn{2}{|l|}{$\begin{array}{l}\text { Status pernikahan Kepala } \\
\text { Keluarga }(n=2.261)\end{array}$} \\
\hline Tidak Menikah & 2,4 \\
\hline Menikah & 85,6 \\
\hline Cerai & 16 \\
\hline \multicolumn{2}{|l|}{ Jenis Kelamin KK $(n=2.264)$} \\
\hline Laki-Laki & 85,5 \\
\hline Perempuan & 14,5 \\
\hline \multicolumn{2}{|l|}{ Pendidikan KK $(n=2.261)$} \\
\hline Tidak Sekolah $(\mathrm{n}=156)$ & 6,9 \\
\hline $\mathrm{SD}(\mathrm{n}=1.116)$ & 49,4 \\
\hline SMP/SMA $(\mathrm{n}=781)$ & 34,5 \\
\hline Pendidikan Tinggi $(\mathrm{n}=208)$ & 9,2 \\
\hline \multicolumn{2}{|l|}{ Indeks Kekayaan $(\mathrm{n}=\mathbf{2 . 2 6 4})$} \\
\hline Sangat Miskin $(\mathrm{n}=316)$ & 14 \\
\hline Miskin $(n=394)$ & 17,4 \\
\hline Menengah $(n=460)$ & 20,3 \\
\hline Kaya $(\mathrm{n}=551)$ & 24,3 \\
\hline Sangat Kaya $(\mathrm{n}=543)$ & 24 \\
\hline \multicolumn{2}{|l|}{$\begin{array}{l}\text { Jumlah Penghuni Rumah Tangga } \\
\text { (N=2.264) }\end{array}$} \\
\hline Rerata ( SD ) & $3,93(1,87)$ \\
\hline
\end{tabular}


Tabel 2 Analisis multivariat dari variabel independen terhadap pemilihan air minum rumah tangga $(n=2.264)$

\begin{tabular}{lccc}
\hline \multicolumn{1}{c}{ Variabel } & AOR & IK 95\% & Nilai p \\
\hline Perkotaan & 1,97 & 1,$53 ; 2,53$ & $<0,001$ \\
Sanitasi memenuhi syarat & 1,69 & 1,$29 ; 2,21$ & $<0,001$ \\
Indeks kekayaan keluarga (sangat miskin) & 0,14 & 0,$08 ; 0,23$ & $<0,001$ \\
Indeks kekayaan keluarga (miskin) & 0,24 & 0,$14 ; 0,40$ & $<0,001$ \\
Indeks kekayaan keluarga (menengah) & 0,36 & 0,$22 ; 0,59$ & $<0,001$ \\
Indeks kekayaan keluarga (kaya) & 0,47 & 0,$29 ; 0,76$ & 0,002 \\
Pendidikan KK (tidak sekolah) & 0,65 & 0,$32 ; 1,34$ & 0,241 \\
Pendidikan KK (SD) & 0,66 & 0,$32 ; 1,34$ & 0,210 \\
Pendidikan KK (SMP) & 1,33 & 0,$70 ; 2,51$ & $<0,001$ \\
Konstanta & 9,12 & & $<0,001$ \\
\hline
\end{tabular}

Tabel 2 menunjukan hubungan multivariabel antara variabel bebas dengan variabel terikat. Menurut persamaan akhir yang didapat, masyarakat yang tinggal di perkotaan memiliki peluang yang lebih besar dan signifikan sebesar 1,97 kali untuk memiliki akses SAM yang aman dibandingkan masyarakat yang tinggal di daerah pedesaan $[\mathrm{AOR}=1,97(\mathrm{IK} 95 \%: 1,53 ; 2,53)]$.

Masyarakat yang memiliki fasilitas sanitasi yang memenuhi syarat berhubungan signifikan terhadap kepemilikan SAM yang aman dibandingkan dengan masyarakat yang tidak memiliki fasilitas sanitasi yang memenuhi syarat $(\mathrm{AOR}=1,69$ (IK 95\%: 1,29;2,21)]. Sementara itu menurut indeks kekayaan, keluarga yang kaya memiliki peluang hampir setengah dari kelurga sangat kaya untuk dapat mengakses SAM [AOR= 0,47 (IK 95\% 0,29;0,76)], sementara keluarga menengah berpeluang signifikan sebesar satu per tiga kali dari keluarga yang sangat kaya [AOR=0,36 (IK 95\% 0,22;0,59)], sedangkan keluarga miskin berpeluang signifikan satu per empat kali dari kelurga sangat kaya $[\mathrm{AOR}=0,24$ (IK95\% 0,14;0,40)] dan pada keluarga sangat miskin berpeluang sebesar satu per tujuh kali dari keluarga sangat kaya untuk dapat mengakses $\mathrm{SAM}[\mathrm{AOR}=0,14(\mathrm{IK} 95 \% 0,08 ; 0,23)]$.

Pada variabel pendidikan KK, diperoleh bahwa masyarakat dengan pendidikan SMP memiliki peluang signifikan sebesar 1,33 kali dari KK dengan pendidikan Perguruan Tinggi (PT) untuk dapat mengakses SAM $[\mathrm{AOR}=1,33$ (IK95\% 0,70;2,51)], pendidikan SD berpeluang 0,66 kali dari KK dengan pendidikan PT untuk dapat mengakses SAM [AOR: 0,66 (IK95\% $0,32 ; 1,34)$ ] sedangkan rumah tangga dengan KK yang tidak berpendidikan formal berpeluang sebesar 0,65 kali dibandingkan dengan KK yang berpendidikan PT untuk dapat mengakses SAM $[\mathrm{OR}=0,65(\mathrm{IK} 95 \%$ 0,32;1,34].

\section{Pembahasan}

Pada sesi diskusi ini, akan disajikan interpretasi dari hasil kajian yang telah dilakukan. Konsisten dengan penelitian sebelumnya, ${ }^{11-14}$ studi ini menemukan bahwa terdapat disparitas geografis antara tempat tinggal di wilayah perkotaan dengan pedesaan, dimana masyarakat yang tinggal di perkotaan memiliki akses yang lebih besar terhadap SAM yang aman. Meskipun menurut Bain dkk, 2014, kemungkinan terdapat "bias perkotaan/ urban bias" dikarenakan terjadi peningkatan populasi yang signifikan diperkotaan daripada di wilayah pedesaan, sehingga hal ini dapat menyebabkan peningkatan jumlah rumah tangga di perkotaan dan akhirnya berpengaruh pada perubahan jumlah sasaran yang menjadi target intervensi program atau cakupan keluarga yang tidak memiliki akses terhadap SAM di daerah perkotaan. ${ }^{14,15}$

Hasil studi juga menunjukan, kepemilikan fasilitas sanitasi yang adekuat berkoresponden dengan akses terhadap SAM yang aman. Hal ini sesuai dengan hasil penelitian NketiahAmponsah dkk (2009) yang menganalisis faktor yang memengaruhi kepemilikan sumber air minum di daerah Sub Sahara Afrika bahwa terdapat hubungan antara keberadaan fasilitas toilet yang bersih dengan kepemilikan SAM yang aman dibandingkan dengan SAM yang tidak aman. Hal ini menunjukkan bahwa, keberadaan air bersih yang aman yang dapat digunakan sebagai sumber air minum dan keperluan hygiene sanitasi memberikan peluang lebih besar untuk dapat meningkat ke tangga sanitasi selanjutnya untuk mengakses sarana sanitasi yang memenuhi syarat.

Penelitian ini juga menemukan variabel sosio-ekonomi yang berhubungan dengan akses terhadap SAM. Indikator sosio-ekomoni yang 
digunakan pada penelitian ini adalah tingkat pendidikan. Literatur terbaru menunjukan hubungan yang positif antara pencapaian tingkat pendidikan seorang kepala keluarga terhadap kepemilikan akses SAM yang aman. ${ }^{13}$ Sejalan dengan hasil penelitian tersebut, studi ini juga menemukan hubungan yang serupa. Semakin tinggi tingkat pendidikan terakhir seorang KK, maka kemungkinan untuk dapat mengakses SAM yang aman pun akan semakin tinggi.

Indikator lainnya dari tingkat rumah tangga yaitu indeks kekayaan, sesuai dengan studi sebelumnya, ${ }^{13,16}$ hasil yang didapat menunjukan terdapat hubungan positif dan signifikan antara indeks kekayaan suatu keluarga terhadap kepemilikan SAM yang aman. Hal ini tidak mengherankan, karena semakin besar pengaruh keuangan sebagai salah satu variabel di tingkat rumah tangga, maka semakin besar kapasitas finansialnya dan mampu menjangkau SAM yang aman.

Dalam pencapaian akses terhadap air minum selama dua dekade, hasil penelitian ini menunjukan masih terdapat disparitas akses SAM di Jawa Barat, begitu pula di Indonesia. ${ }^{14,17,18}$ yang merupakan tantangan terbesar khususnya dalam pencapaian akses semesta 2019 (Universal Acces). Pemerintah melalui Menurut Rencana Pembangunan Jangka Menengah 2015-2019 telah merencakan berbagai upaya untuk dapat mencapai akses universal sesuai target. Salah satu upaya untuk dapat memecahkan tantangan tersebut adalah dengan menyusun suatu kerangka konsep (framework) dalam hal regulasi dalam upaya penyediaan SAM yang berkelanjutan dengan melibatkan kekuatan pemerintah lokal (daerah). Salah satu upaya pemerintah untuk dalam hal penyediaan SAM yang aman khususnya di wilayah perkotaan dengan membentuk suatu perusahaan sebagai pengelola (Perusahaan Air Minum Daerah, PDAM) dimana pelayanan untuk masyarakat pedesaan belum keseluruhan terjangkau, pun di daerah periurban atau pinggiran kota yang sebagian besar merupakan slum-area (daerah kumuh). Hingga pada tahun 1990-an pemerintah mengembangkan penyediaan air minum berbasis komunitas seperti program Water and Sanitation for Low Income Community (WSLIC), Sanitasi dan Air Minum Berbasis Masyarakat (SANIMAS), hingga Program Penyediaan Air Minum dan Sanitasi Berbasis Masyarakat (PAMSIMAS) namun capaian akses masyarakat terhadap SAM yang aman masih jauh dari target. Universal Acces di tahun 2019 tidak dapat dicapai dengan program yang ada, diperlukan suatu strategi khusus untuk dapat mengakseselerasi hasil pencapaian. Pencapaian akses terhadap SAM yang aman pada tahun 2013 sebesar 57,8\% sedangkan target 2019 sebesar $100 \%$, dalam kurun waktu empat tahun terhitung 2016 terdapat $42,2 \%$ target yang harus diselesaikan. Selisih ini harus diselesaikan dalam waktu yang singkat.

Penelitian ini memiliki beberapa keterbatasan, antara lain; Penelitian ini menggunakan desain cross-sectional sehingga sangat lemah untuk diinterferensikan dalam hubungan sebab akibat; Penelitian ini menggunakan data SDKI yang merupakan survei berbasis reproduksi sehingga informasi yang berkaitan dengan penggunaan air bersih ataupun air minum tidak terdapat secara detail. Namun disisi lain, survei ini dilakukan di seluruh provinsi yang ada di Indonesia dengan jumlah sampel dan jangkauan yang luas.

Kesimpulan, studi ini bertujuan untuk mengetahui faktor yang dapat menentukan kepemilikan SAM tingkat rumah tangga di Jawa Barat. Salah satu yang ditemukan dalam studi ini bahwa masih terdapat disparitas antara penduduk perkotaan dengan pedesaan dalam mengakses SAM yang aman. Hal ini dapat memengaruhi terhadap perbedaan penyakit yang ditimbulkan dari rendahnya akses terhadap SAM. Selain itu, kepemilikan fasilitas sanitasi yang memenuhi syarat berhubungan erat dengan akses SAM yang aman. Tingkat pendidikan dan indeks kekayaan keluarga memiliki hubungan yang positif dengan kepemilikan SAM yang aman. Semakin tinggi pendidikan dan kekayaan keluarga, semakin besar akses terhadap SAM yang aman.

\section{Daftar Pustaka}

1. Benelam B, Wyness L. Hydration and health: A review. Nutrition Bulletin. Blackwell Publishing Ltd; 2010. p. 3-25.

2. WHO. The Right to Water. Health and Human Rights Publication Series. 2003.

3. WHO,UNICEF. Joint MonitoringProgramme on Water Supply and Sanitation. 2000.

4. Assembly TG, Nations U, Conference W, Rights C, Rights P. General Assembly. Environment. 2010;1249(20378):9-11.

5. United Nations. The Millennium Development Goals Report. United Nations. 2015;72.

6. Kementerian Negara Perencanaan Pembangunan Nasional (Bappenas). Buku I Agenda Pembangunan Nasional. 2014;1-289.

7. Badan Pusat Statistik (BPS). Profil Penduduk Indonesia Hasil Supas 2015 [Internet]. 2015. 273 p. Available from: https://www.bps.go.id

8. Adam FP. Tren urbanisasi di indonesia. Piramida. 2010;6(1):1-15.

9. United Nations General Assembly. Transforming our world: The 2030 agenda 
for sustainable development. https// sustainabledevelopment.un.org/content/ documents/7891Transforming\%200ur\%20 World pdf. 2015;(1):1-5.

10. Hosmer DW, Lemeshow S SR. Applied Logistic Regression, 3rd Edition. Wiley. 2013. $518 \mathrm{p}$.

11. Hopewell M, Graham J. Trends in access to water supply and sanitation in 31 major subSaharan African cities: an analysis of DHS data from 2000 to 2012. BMC Public Health. 2014;14:208.

12. Fotue ALT, Sikod, F. Determinants of households choice of drinking water source in Cameroon. J Sustain Dev Africa. 2012;14:86-97.

13. Adams E., Boateng GO, Amoyaw J. Sosioeconomics and demographic predictors of potable water and sanitation acces in Ghana. Soc Indic Res. 2015;1-15.
14. Bain RE., Wright J., Christenson E, Bartram J. Rural:urban inequalities in post 2015 targets and indicators for drinking-water. Sci Total Environ. 2014;490:509-13.

15. WHO/UNICEF. Progress on sanitation and drinking-water: 2013 update. $\mathrm{WHO} /$ UNICEF; 2013.

16. Rahut D., Behera B, All A. Household access to water and choice of treatment methods: Empirical evidence from Buthan. Water Resour Rural Dev. 2015;5:1-16.

17. Patunru AA. Access to safe drinking water and sanitation in Indonesia. Asia Pacific Policy Stud. 2015;2(2):234-44.

18. Irianti S, Prasetyoputra P, Sasimartoyo TP, Lee A. Determinants of household drinkingwater source in Indonesia: An analysis of the 2007 Indonesian family life survei. Cogent Med. 2016;3(1):1151143. 